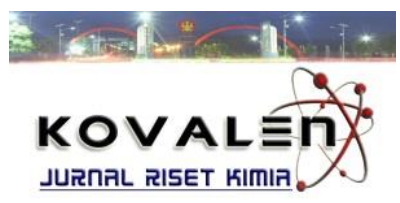

\title{
STABILITAS EKSTRAK WARNA BUNGA ASOKA (Ixora javanica) BERDASARKAN VARIASI pH SELAMA MASA PENYIMPANAN
}

\section{Effect of pH in The Stability Of Natural Dyes from Ashoka (Ixora javanica) During The Storage Period}

\author{
Elditna Jenianti Putri ${ }^{{ }^{\star}}$, Nurhaeni ${ }^{1}$, Pasjan Satrimafitrah ${ }^{1}$, Dwi Juli Puspitasari ${ }^{1}$ \\ 1) Jurusan Kimia, Fakultas MIPA, Universitas Tadulako, Palu \\ J. Soekarno Hatta Km.9, Kampus Bumi Tadulako Tondo Palu, Telp. 0451- 422611
}

*)Coresponding author: elditnajeniantiputri@gmail.com

Diterima 27 Mei 2019, Disetujui 25 Juli 2019

\begin{abstract}
Research on the potential of Ashoka (Ixora javanica) flower as a natural food and beverage coloring agent in terms of $\mathrm{pH}$ stability during the storage period. This study aims to determine the stability of Asoka flower extract on the effect of $\mathrm{pH}$ during the storage period. The time used was 10 days and the variation of $\mathrm{pH}$ of $2,3,4,5$ and 6 , respectively. The results show that Asoka flower extract was stable at $\mathrm{pH} 2$ after a 10-day storage period with degradation presentation of $36.21 \%$, while Ashoka flower extract dyes were unstable at $\mathrm{pH} 6$ after a 10-day storage period with degradation percentage is $78.02 \%$. This proves that the different acidic atmosphere influences the stability of Ashoka flower extract.
\end{abstract}

Keywords : Dyes, stability of Ashoka flowers, degradation

\begin{abstract}
ABSTRAK
Telah dilakukan penelitian tentang potensi bunga asoka (Ixora Javanica) sebagai pewarna alami makanan dan minuman yang ditinjau dari stabilitas $\mathrm{pH}$ selama masa penyimpanan. Penelitian ini bertujuan untuk mengetahui kestabilan ekstrak bunga asoka terhadap pengaruh $\mathrm{pH}$ selama masa penyimpanan. Waktu yang digunakan adalah 10 hari, variasi $\mathrm{pH}$ yang digunankan pada penelitian ini yaitu $\mathrm{pH} 2,3,4,5,6$. Hasil penelitian menunjukan zat warna ekstrak bunga asoka stabil pada $\mathrm{pH} 2$ setelah masa penyimpanan 10 hari dengan presentasi degradasi $36.21 \%$, sedangkan zat warna ekstrak bunga asoka yang tidak stabil pada $\mathrm{pH} 6$ setelah masa penyimpanan 10 hari dengan presentasi degradasi $78,02 \%$. Hal ini membuktikan bahwa suasana asam yang berbeda berpengaruh terhadap kestabilan ekstrak bunga asoka.
\end{abstract}

Kata Kunci : Zat warna, stabilitas bunga asoka, degradasi 


\section{LATAR BELAKANG}

Di Indonesia tanaman asoka (Ixora sp.) merupakan tanaman hias yang cukup populer dikalangan penghobi tanaman hias. Selain unik, bentuk dan jenisnya pun beragam. Ada yang asli berasal dari dalam negeri yaitu asoka Jawa (Ixora javanica), ada pula yang berasal dari luar negeri seperti India dan China, dan sekarang telah hadir tanaman asoka baru yang disebut asoka hibrida. Selain jenisnya beragam, tanaman hias ini mempunyai berbagai keuntungan, artinya tidak hanya untuk tanaman indoor saja seperti mengisi sudut-sudut rumah, namun juga bisa untuk tanaman outdoor terutama untuk pembatas pagar. Dengan perawatan yang teratur, tanaman ini bisa bertahan sampai beberapa tahun.Tanaman ini berasal dari daerah Asia. Bahkan ada yang menyebutkan berasal dari negara Indonesia. Namun sejauh ini belum teruji kebenarannya, yang pasti dengan ditemukannya jenis bunga asoka kuno yaitu (Ixora javanica) di pulau Jawa telah cukup menjadikannya alasan mengapa tanaman tersebut berasal dari negara kita. Dugaan kuat mengenai asal usul tanaman ini lebih cenderung kepada negara India dan China, dimana di dua negera tersebut memiliki beragam jenis tanaman asoka. (Widjajati, 2012).

Penggunaan pewarna sintesis dapat berbahaya bagi manusia karena dapat menyebabkan kanker kulit, kanker mulut, kerusakan otak dan lain-lain. serta menimbulkan dampak bagi lingkungan seperti pencemaran air dan tanah yang juga berdampak secara tidak langsung bagi kesehatan manusia karena di dalamnya terkandung unsur logam berat seperti Timbal (Pb), Tembaga(Cu),dan Seng (Zn) yang berbahaya. (Hanum, 2000).

Berkembangnya industri pengolahan pangan dan terbatasnya jumlah serta kualitas zat pewarna alami menyebabkan pemakaian zat warna sintetis meningkat. Pewarna sintetis pada makanan kurang aman untuk konsumen karena diantaranya ada yang mengandung logam berat yang berbahaya bagi kesehatan. Oleh sebab itu, perlu ditingkatkan pencarian alternatif sumber zat pewarna alami. Zat pewarna alami yang berpotensi untuk diekstrak diantaranya adalah antosianin (Hanum, 2000). Menurut Winarno (1995) dalam Neliyanti (2014), zat warna yang diperoleh dari tumbuhan akan mengalami perubahan pada beberapa kondisi, tergantung dari jenis zat warna yang terkandung dalam tumbuhan tersebut. Penggunaan zat warna antosianin pada produk olahan pangan dipengaruhi oleh beberapa faktor, diantaranya stabilitas pewarna alami terhadap kondisi lingkungan seperti perubahan $\mathrm{pH}$, paparan cahaya, suhu, dan volume. Menurut Kumalaningsih (2006), aplikasi antosianin sebagai pewarna makanan dan minuman dapat dilakukan pada $\mathrm{pH}$ rendah seperti untuk minuman ringan, minuman berakohol, manisan, saos, pikel, makanan beku atau kelengan serta yoghurt. Antosianin dapat diperoleh 
dari beberapa tumbuhan salah satunya bunga asoka.

Pada penelitian Rundubelo et al. (2019) menggunakan ekstrak antosianin ubi banggai (Dioscorea bulbifera var celebica Burkill). Setelah masa penyimpanan selama 10 hari ekstrak ubi banggai mengalami degradasi pada masing-masing variasi $\mathrm{pH} 2,3,4,5$, dan 6 sehingga stabilitas zat warna menurun. Penurunan tertinggi pada $\mathrm{pH} 4$ sebesar $83,73 \%$ dan terendah pada $\mathrm{pH} 2$ sebesar 37,38 \%. Suhartatik et al. (2013) menggunakan ekstrak antosianin beras ketan (Oryza Sativa Var. Glutinosa) dan menghasilkan ekstrak antosianin mengalami penrunan setelah disimpan selama 5 hari dan ekstrak antosianin yang disimpan pada suhu kamar akan stabil pada $\mathrm{pH} 6$.

\section{METODOLOGI PENELITIAN}

\section{Bahan dan Peralatan}

Bahan yang digunakan pada penelitian ini adalah bunga asoka; buffer klorida $\mathrm{pH} 2$; buffer sitrat $\mathrm{pH} 3,4,5$ dan 6; etanol 96\%; kertas saring; aluminium foil; dan akuades.

Alat yang digunakan pada penelitian ini adalah loyang, gelas ukur (10, 100 dan $500 \mathrm{ml}$ ), botol vial, seperangkat alat sentriguge, pipet tetes, corong kaca, pipet volum $1 \mathrm{ml}$, rotari vakum eveporator, corong buchner, pompa vakum, labu ukur $25 \mathrm{ml}$, sendok zat $\mathrm{pH}$ meter, spektrofotometer UV-Vis (Perkinelmer), alat pengocok (shaker) dan alat-alat gelas lainnya.

\section{Prosedur Kerja}

Penelitian dilakukan dalam beberapa tahap yaitu preparasi sampel, ekstaksi, penentuan panjang gelombang maksimum, penentuan absorbansi awal dan uji stabilitas.

\section{Preparasi sampel}

Bunga asoka yang diperoleh dibersihkan dari batangnya. Kemudian dicuci dengan air mengalir. Lalu di ekstraksi.

\section{Ekstraksi Bunga Asoka (Rundubelo et al., 2019)}

Proses ekstraksi dilakukan dengan metode meserasi 24 jam. Bunga asoka ditimbang sebanyak $500 \mathrm{~g}$ lalu dimasukkan ke dalam wadah kedap cahaya, selanjutnya ditambahkan $1000 \mathrm{ml}$ etanol 96\% dengan rasio perbandingan antara sampel dan pelarut sebesar 1:2 (b/v), lalu ditutup rapat. Setelah itu dikocok selama 1 jam setiap 6 jam menggunakan alat pengocok (shaker). Kemudian disaring menggunakan corong buchner dengan bantuan pompa vakum untuk memisahkan ekstrak dari residu. Ekstrak yang didapatkan kemudian dipisahkan dari pelarutnya dengan menggunakan rotari vakum evaporator.

\section{Penentuan Panjang Gelombang Maksimum (Rundubelo et al., 2019)}

Diambil $1 \mathrm{ml}$ ekstrak etanol bunga asoka dengan pipet volum $1 \mathrm{ml}$ lalu dimasukan ke dalam labu ukur $25 \mathrm{ml}$ 
kemudian ditambahkan akuades sampai tanda batas. Kemuadian ditentukan panjang gelombang maksimum menggunakan spektrofotometer UV-Vis.

\section{Penentuan Absorbansi (Rundubelo et al., 2019)}

Awal

Diambil $1 \mathrm{ml}$ ekstrak etanol bunga asoka dengan pipet volum $1 \mathrm{ml}$ lalu dimasukan ke dalam labu ukur $25 \mathrm{ml}$ kemudian ditambahkan akuades sampai tanda batas. Kemudian diukur absorbansinya menggunakan spektrofotometer UV-Vis. Perlakuan dilakukan sebanyak 3 kali.

\section{Uji Stabilitas Ekstrak Bunga Asoka} Berdasarkan Pengaruh pH Selama Masa Penyimpanan (Yudiono, 2011)

Diambil $1 \mathrm{ml}$ ekstrak bunga asoka dengan pipet volum $1 \mathrm{ml}$ lalu dimasukan ke dalam masing-masing 5 labu ukur $25 \mathrm{ml}$ lalu ditambahkan larutan penyangga yang telah disediakan pada masing-masing labu ukur secara berturut-turut yaitu penyangga $\mathrm{pH} 2,3,4,5$ dan 6sampai tanda batas. Kemudian disiapkan wadah yaitu botol vial yang telah dibungkus dengan aluminium foil dan diberi label $\mathrm{pH} 2,3,4,5$ dan 6 . Kemudian masing-masing botol vial diisi dengan larutan dari labu ukur sesuai dengan $\mathrm{pH}$ masing-masing botol yang tersedia dan diletakan pada suhu ruang. Sampel disimpan selama masa penyimpanan 10 hari dan diukur absorbansinya pada panjang gelombang $550 \mathrm{~nm}$ setiap 24 jam sekali menggunakan spektrofotometer UV-Vis. Perlakuan di gunakan sebanyak dua kali. Lalu menghitung degradasi zat warna dengan menggunakan persamaan berikut :

Degradasi $(\%)=\frac{A o-A t}{A o} \times 100 \%$

Dimana :

$A o=$ absorbansi sebelum dilakukan pengujian

At $=$ absorbansi setelah di lakukan pengujian terhadap waktu

\section{HASIL DAN PEMBAHASAN}

\section{Ekstrak Bunga Asoka}

Ekstrak pekat bunga asoka pada penelitian ini diperoleh dengan metode ekstraksi maserasi selama 24 jam. Pemilihan metode maserasi ini dikarenakan prosesnya sederhana dan dilakukan tanpa pemanasan, sehingga tidak merusak pigmen yang terkandung dalam bunga asoka. Yang menjadi penekanan dalam metode ini adalah tersedia waktu kontak yang cukup antara pelarut dengan sampel yang akan diekstrak. Menurut Hanum (2000), maserasi dilakukan dengan cara merendam sampel dalam cairan pelarut. Pelarut akan menembus dinding sel dan masuk kedalam rongga sel yang mengandung zat aktif. Dari proses ini ekstrak yang diperoleh dipisahkan pelarutnya dan dipekatkan dengan cara evaporasi menggunakan rotari vakum evaporator dan diperoleh ekstrak pekat berwarna merah sebanyak $150 \mathrm{ml}$. Ekstrak yang diperoleh diasumsikan sebagai antosianin sebagaimana menurut Achmad (1986), antosianin adalah senyawa yang berperan dalam memberikan warna merah, 
ungu dan biru pada beberapa bagian tumbuhan misalnya kelopak bunga dan buah.

Pelarut yang digunakan pada proses ini adalah etanol $96 \%$, pelarut ini dipilih karena merupakan pelarut organik yang bersifat polar. Menurut Wulaningrum (2013), Senyawa golongan flavonoid termasuk senyawa polar dan dapat diekstraksi dengan pelarut yang bersifat polar pula (like dissolve like).

Menurut Andersen dkk (2001) dalam Wulaningrum (2013), salah satu pigmen yang dapat diekstrak dari sumber bahan alami adalah antosianin yang termasuk golongan senyawa flavonoid. Pigmen ini berperan terhadap timbulnya warna merah hingga biru pada beberapa bunga, buah, daun dan umbi.

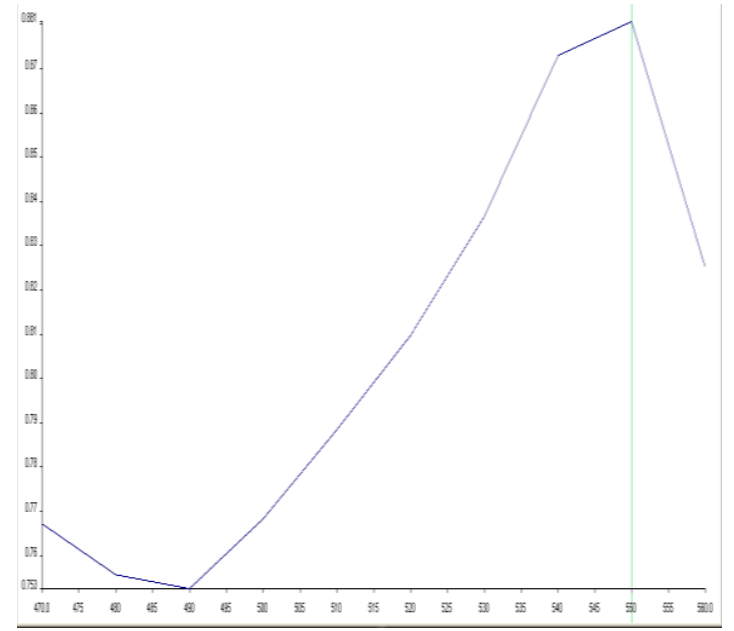

Gambar 1 Panjang gelombang maksimum ekstrak bunga asoka dengan Spektrofotometer UV-Vis

Ekstrak bunga asoka ditentukan jenis senyawanya dengan menggunakan analisis kualitatif menggunakan spektrofotometer UV-Vis. Panjang gelombang maksimum ditentukan dengan mengukur sampel ekstrak bunga asoka pada rentang panjang gelombang 470-560 $\mathrm{nm}$. Hasil pengukuran didapatkan bahwa nilai absorbansi maksimum ekstrak bunga asoka yaitu $550 \mathrm{~nm}$ (Gambar 4.1). Hasil ini berada pada serapan senyawa antosianin yang terletak pada panjang gelombang 490-580 nm (Harborne, 1996).

Panjang gelombang $550 \mathrm{~nm}$ ini digunakan untuk menentukan absorbansi awal $\left(A_{0}\right)$ antosianin. Hasil yang diperoleh berdasarkan pengukuran dengan tiga kali pengulangan, yaitu 0,$521 ; 0,550$; dan 0,540 dengan rata-rata absorbansi awal $\left(A_{0}\right)$ adalah 0,537. Absorbansi awal akan digunakan selanjutnya pada penentuan degradasi pigmen ekstrak buna asoka.

\section{Stabilitas Ekstrak Bunga Asoka Terhadap Pengaruh pH Selama Masa Penyimpanan}

Dari hasil uji stabilitas lilakukan selama masa penyimpáııı 10 hari diketahui degradasi terendah pada $\mathrm{pH} 2$ sebesar $36,21 \%$.

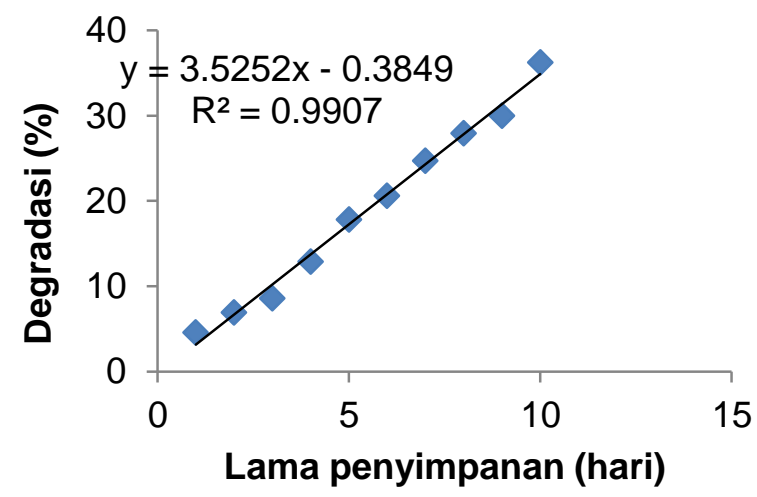

Gambar 2 Degradasi zat warna terhadap pengaruh $\mathrm{pH} 2$ selama masa penyimpanan 
Pada (Gambar 2) ditunjukan bahwa pH 2 merupakan kondisi keasaman yang tepat pada kestabilan pigmen antosianin. Pada $\mathrm{pH} 3,4,5$ dan 6 antosianin mengalami degradasi yang lebih tinggi dari pada $\mathrm{pH} 2$, sehingga suasana asam yang berbeda mempengaruhi kestabilan zat warna bunga asoka. Menurut (Francis, 1992 dalam Hidayah et al., 2014), semakin rendah nilai $\mathrm{pH}$ maka warna konsentrat makin merah dan stabil atau jika $\mathrm{pH}$ semakin mendekati satu maka warna semakin stabil. Juga pada hasil penelitian yang dilakukan Hidayah et al. (2014), terlihat pada kondisi asam zat warna ekstrak kulit buah naga mengalami penurunan serapan yang dapat dilihat dari warna ekstrak dan absorbansi yang dihasilkan pada panjang gelombang maksimum.

Pada penelitian ini diperoleh kestabilan pigmen warna pada $\mathrm{pH} 2$ hingga hari ke-10, yaitu $36,21 \%$. Suhartatik et al., (2013) menyatakan bahwa batas kestabilan pigmen antosianin tidak lebih dari $50 \%$. Hasil yang diperoleh telah memenuhi standar kestabilan pigmen warna antosianin. Menggunakan analisis regresi, waktu penyimpanan dapat diatur dengan persamaan $y=3,525 x-0,3849$. Hasil perhitungan menunjukan bahwa ekstrak bunga asoka memiliki kestabilan atau usia simpan hingga 14 hari atau degradasi pigmen masih $<50 \%$.

Pada saat ekstrak ditambahkan larutan buffer terlihat terjadi perubahan warna dimana semakin tinggi nilai $\mathrm{pH}$ maka warna ekstrak semakin memudar, hasil ini sesuai dengan penelitian Mastuti et al. (2013), bahwa dalam hal warna, semakin tinggi nilai $\mathrm{pH}$ dalam suasana asam warna ekstrak akan menjadi pudar. Menurut Hidayah et al. (2014), peningkatan $\mathrm{pH}$ akan membuat warna antosianin memudar karena kation flavilium yang berwarna merah mengalami hidrasi menjadi karbinol yang tidak berwarna.
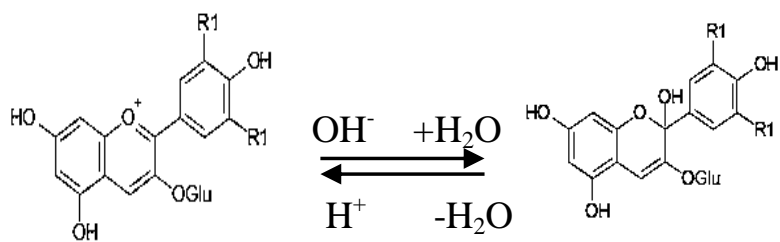

Gambar 3 Perubahan struktur antosianin dari bentuk kation flavilium menjadi karbinol (Hayati, dkk. 2012)

Menurut Rein (2005) dalam Neliyanti (2014), di bawah $\mathrm{pH}$ rendah, antosianin berada dalam bentuk kation flavilium merah. Saat $\mathrm{pH}$ dinaikkan (> 5), akan mempercepat kehilangan proton sehingga membentuk basa quinoidal yang cenderung menjadi biru atau ungu. Selain itu, kenaikan $\mathrm{pH}$ menyebabkan hidrasi kation flavilium untuk membentuk karbinol yang tidak berwarna.

\section{KESIMPULAN}

Setelah masa penyimpanan selama 10 hari ekstrak bunga asoka mengalami degradasi terendah pada $\mathrm{pH} 2$ yaitu sebesar 36,21\%. Perlu dilakukan perlu dilakukan pengaplikasian ekstrak bunga asoka pada produk olahan makanan maupun minuman. 


\section{DAFTAR PUSTAKA}

Achmad, S, A. 1986. Buku Materi Pokok Organik Bahan Alam. Jakarta: Penerbit Kurnika.

Rundubelo, B A., Ridhay, A., Hardi, J., Puspitasari, D J. 2019. Uji Stabilitas Pigmen Ekstrak Ubi Banggai (Dioscorea Bulbifera Var Celebica Burkill) Pada berbagai Variasi $\mathrm{pH}$ Dan Lama Paparan Sinar Matahari. KOVALEN: Jurnal Riset Kimia, 5(1): 9-16

Hanum, T. 2000. Ekstraksi dan Stabilitas Zat Pewarna Alam Dari Katul Beras Ketan (Oryza sativa glutinosa). Buletin Teknologi dan Industri Pangan XI (1) : 17-23

Harborne, J, B. 1996. Metode Fotokimia. Penuntun Cara Modern Menganalisis Tumbuhan. Alih Bahasa Kosasih Padmawinata. Bandung: Institut Tehnologi Bandung.

Hidayah, et al. 2014. Uji Stabilitas Pigmen Dan Antioksidan Ekstrak Zat Warna Alami Kulit Buah Naga. Indonesian Journal of Chemical Science, 3 (2).

Kumalaningsih, S. 2006. Antioksidan Alami. Surabaya: Trubus Agrisarana.

Mastuti, E., Fristiyaningrum, G., Andika, Y. 2013. Ekstraksi dan Uji Kestabilan Warna Pigmen Antosianin Dari Bunga Talang (Clitoria Ternatea L.) Sebagai Bahan Pewarna Makanan. Prosiding Simposium Nasional Rekayasa Aplikasi Perancangan dan Industri. Simposium Nasional Ke-12 RAPI 2013. Surakarta: UMS.

Neliyanti. 2014. Ekstraksi Dan Uji Stabilitas Zat Warna Alami Dari Buah Lakum (Cayratia trifolia (L.) Domin). JKK, 3 (2): $30-37$

Suhartatik, N., Karyantina, M., Mustofa, A., Cahyanto, M N., Raharjo, S., Rahayu, E S. 2013. Stabilitas Ekstrak Antosianin Beras Ketan (Oryza sativa var. Glutinosa ) Hitam Selama Proses Pemanasan dan Penyimpanan. agriTech, 33(4).
Wulaningrum, R, A. 2013. Pengaruh Asam Organik Dalam Ekstraksi Zat Warna Kulit Buah Manggis (Garcinia mangostana). Indonesian Journal of Chemical Science, 2 (2).

Yudiono, K. 2011. Ekstraksi Antosianin Dari Ubi Jalar Ungu (Ipomea Batatas Cv. Ayamurasaki) Dengan Teknik Ekstraksi Subcritical Water. Jurnal Teknologi Pangan, 2 (1): 1-30 